\title{
Effect of Fertilizer and Storage Period on Oxidative Stability and Color of Rapeseed Oils
}

\section{Magdalena Kachel-Jakubowska ${ }^{1 *}$, Agnieszka Sujak², Marta Krajewska ${ }^{3}$}

${ }^{1}$ Department of Machinery Exploitation and Management of Production Processes, University of Life Sciences in Lublin, Głęboka 28, 20-612 Lublin, Poland

${ }^{2}$ Department of Biophysics, University of Life Sciences in Lublin,

Akademicka 13, 20-930 Lublin, Poland

${ }^{3}$ Department of Biological Bases of Food and Feed Technologies, University of Life Sciences in Lublin,

Głęboka 28, 20-612 Lublin, Poland

Received: 22 March 2017

Accepted: 24 May 2017

\begin{abstract}
We analysed physical and chemical properties of seeds and oils from different cultivars of winter rapeseeds ('Markus', 'Bios' and 'Feliks') that were cultivated using bio-gas natural manure (digestate) or with a commercially accessible Yara NPK 5014-28 (NPK) fertilizer, both of which were analyzed for element content. Seeds produced without use of fertilizers were taken as control. Prior to cold-pressing of oils, seeds were analyzed for fatty acid content. Cultivar 'Bios' breed with use of digestate showed a lower amount of oleic acid (C18:1), while the 'Feliks' cultivar had higher content of this fatty acid and lower amounts of linoleic acid (C18:2) as compared to respective controls. In the case of the application of NPK fertilizer, the increase in C18:1 was observed for the cultivars 'Markus' and 'Feliks'. In the latter the decrease in the content of C18:2 was observed as compared to control. The oils were analyzed monthly for photosynthetic pigment content and oxidative stability as well as color during a storage period of three months. Oils contained similar amounts of chlorophylls and carotenoids. Oils derived from seeds produced with the use of commercial NPK fertilizer were characterized with higher oxidation stability (induction time) as compared to digestate. Gradual darkening of the oils was observed. Statistical analysis $(p<0.05)$ showed significant correlation between all the color parameters and term of measurements as well as with the applied fertilizer.
\end{abstract}

Keywords: digestate, cold-pressed oils, carotenoids, colors of oil

*e-mail: magdalena.kacheljakubowska@up.lublin.pl 


\section{Introduction}

Production of the traditional foods following the guidelines for sustainable agriculture results from caring for health and the environment [1-3]. This is usually achieved by applying temporary crops and the use of environmentally friendly fertilizers where one of the concerns is the quality of soil. Fermentation is a well-known process leading to the production of biogas and digestate. The latter, containing organic matter, is a valuable fertilizer from the point of view of plant nutrition [4]. It contains significant amounts of minerals (nitrogen, phosphorus, and potassium) and therefore can act similarly to mineral fertilizers, where nutrients are readily available for plants.

Recent years have seen an increased interest in using natural and safe food, including oils and fats. Rapeseed (Brassica napus L.) is one of the most important oilseed crops grown around the world [5]. Oil pressed from rapeseeds has been classified as a valuable edible fat, mainly due to the high level (approx. 90\%) of unsaturated fatty acids and low saturated fatty acids (6\%) [6]. Consumption of vegetable oils, among others, helps to regulate the administration of lipids within the body by lowering cholesterol and triglycerides in the blood plasma. It also plays a protecting role against diseases caused by the reactive forms of oxygen and acting as a filter of shortwave radiation [6-10]. Vegetable oils are also reported to reduce the risk of heart attack, stroke, coronary heart disease, cataracts, Alzheimer's disease, and cancer [6]. Minor components such as carotenoids or chlorophylls are responsible for the coloring of virgin or even refined oils [11]. During the process of cold-extraction these pigments permeate to oil from seeds in amounts depending on the seed species, environmental conditions, degree of seed maturity, or the storage process. They affect the color of the oil, which is one of the basic quality characteristics of the obtained product, thereby affecting consumer preferences, while they often make the decision to purchase on this basis [12-14]. Concerning the content of chlorophyll in seeds, at full maturity stage it usually amounts to $1-2 \mathrm{ppm}$, while in the case of physiologically matured seed (35 days before maturity) it can be as high as $1,239 \mathrm{ppm} \mathrm{[15].} \mathrm{It} \mathrm{is} \mathrm{important} \mathrm{to} \mathrm{note} \mathrm{that} \mathrm{the}$ chlorophyll concentration does not exceed $25 \mathrm{mg} / \mathrm{kg}$ [16]. High chlorophyll content negatively affects the quality of oils by affecting smell as well as stability as it can possess pro-oxidative properties, thus resulting in a darkening of the oil. Carotenoids are considered very important due to their antioxidant and pro-vitamin activity, and compounds reducing the risk of certain cancers or cardiovascular diseases [17-20]. Adverse changes in the oils can be caused by chemical or biochemical processes initiated previously in the oilseeds. Chemical processes occurring under the influence of physical and chemical factors such as the availability of oxygen and light or elevated temperature dominate the state of the oil. Therefore, the conditions of storage during which oils undergo unwanted changes due to hydrolysis or auto-oxidation are significant. The range of oxidative alterations of oils depends on storage conditions such as temperature, oxygen and light access, and the type of packaging. On contact with oxygen, it is possible to initiate free radical chain reactions in fats [21]. Light can initiate oxidation with singlet oxygen which is characterized by an extremely high reactivity [22-24]. In addition, various studies have shown that the oxidative stability of vegetable oils strongly depends on its chemical composition and on the reactions between the unsaturated fatty acids and reactive oxygen species [2527]. Furthermore, the rate of oxidation of individual fatty acids depends on the degree of unsaturation and especially on the oxidation of oleic acid (C18:1), linolenic acid (C18:2), and $\alpha$-linolenic (C18: $3 \mathrm{n} 3$ ) acid [28-30]. Oxidative stability of oils can be defined as a sort of its resistance to oxidation. This is one of the most important indicators of suitability for human consumption. The types and amounts of the compounds that are oxidation products in the oil depend mainly on the fatty acid composition and on storage conditions. The main factor limiting the oxidation of lipids is the presence of natural antioxidants [31] of different chemical structure, which may affect the antioxidant activity and the rate of oxidation of the oils [32]. The cooking oil should preferably have high stability and resistance to oxidation during long-term use [33]. However, the acceptable level of stability may be different for the same type of oil due to the differences in the oxidative state at the beginning of the storage period [34-35]. The aim of our study was to:

1. Compare the properties of rapeseed from plants cultivated using of two types of fertilizers by analysis of fatty acids content.

2. Compare the quality of obtained oils by analyzing their photosynthetic pigments content, oxidation stability, and color.

\section{Materials and Methods}

\section{Experimental Material}

The research material consisted of three cultivars of seeds of spring rape - 'Markus', 'Bios' and 'Feliks' from the Strzelce Plant Breeding Station, limited liability company. Experiments were conducted on micro plots (27 $\mathrm{m}^{2}$ each) on light silty soil originating from loess soil characterized by a high amount of fine silt, which keeps the water very well, is not susceptible to heating, and has a tendency to form a crust after rainfall ( $\mathrm{pH}$ 7.37). Wheat was used as a forecrop. Seeds were sown in March and crops were collected after reaching full maturity stage in August. Two experimental combinations were used. In the first combination, digestate derived from a biogas plant was used prior to sowing (Bio-Tech limited liability company in Piaski, Lublin Province, Poland: electrical power $0.99 \mathrm{MW}$, heat power $-1.1 \mathrm{MW}$, annual production of energy c.a. 8,400 MWh) in the amount of $97.2 \mathrm{~L} /$ plot $\left(36 \mathrm{~m}^{3} / \mathrm{ha}\right)$. Silage corn, whey, and green wastes were used as an input in a biogas plant to produce biogas and natural 
manure (digestate). Before use, digestate was analyzed for the content of macro elements and heavy metals (Table 1). The $\mathrm{pH}$ of the digestate used for the cultivation of spring rape was 8.73 . Analyses were performed by the Regional Agrochemical Station in Lublin, Poland.

In the second variant the commercial multi-compound fertilizer Yara NPK 5-14-28 was applied (5\% ammoniacal nitrogen, $14 \% \mathrm{P}, 28 \% \mathrm{~K}, 12.5 \% \mathrm{SO}_{3}$, and $3 \% \mathrm{CaO}$ ) in the amount of $0.405 \mathrm{~kg} /$ plot $(150 \mathrm{~kg} / \mathrm{ha})$. Doses of each fertilizer were chosen on the basis of the producer recommendations. Each experiment was conducted in triplicate and was accompanied with a control without the addition of manure or NPK fertilizer.

After ripening, the seeds were harvested manually, cleaned of the rendered dust, and then left in a laboratory at $20^{\circ} \mathrm{C}$ in $60-70 \%$ humidity (to compensate for humidity for a month).

\section{Fatty Acid Content}

Seeds were analyzed for the fatty acid content in accordance with PN-EN ISO 5509: 2001 (oils and fats of plant and animal origin - analysis of fatty acid methyl esters by gas chromatography) at the Central AgroEcological Laboratory, University of Life Sciences in Lublin.

\section{Oil Extraction}

Seeds with moisture content of $9 \%$ were subjected to cold pressing. The oil was pressed using a screw press with variable nozzle with a diameter of $8 \mathrm{~mm}$ and a set of

Table 1. Total contents of macronutrients and selected heavy metals in digestate used for cultivating spring rape.

\begin{tabular}{|c|c|}
\hline Element & Content \\
\hline $\mathrm{N}(\mathrm{g} / \mathrm{L})$ & $0.119^{*}$ \\
\hline $\mathrm{P}(\mathrm{g} / \mathrm{L})$ & $0.12^{* *}$ \\
\hline $\mathrm{K}(\mathrm{g} / \mathrm{L})$ & $5.37^{* *}$ \\
\hline $\mathrm{Ca}(\mathrm{g} / \mathrm{L})$ & $0.28^{* *}$ \\
\hline $\mathrm{Mg}(\mathrm{g} / \mathrm{L})$ & $0.07^{* *}$ \\
\hline $\mathrm{Cd}(\mathrm{mg} / \mathrm{L})$ & $<0.43$ \\
\hline $\mathrm{Pb}(\mathrm{mg} / \mathrm{L})$ & $<0.43$ \\
\hline $\mathrm{Ni}(\mathrm{mg} / \mathrm{L})$ & $<0.43$ \\
\hline $\mathrm{Cr}(\mathrm{mg} / \mathrm{L})$ & $<0.43$ \\
\hline $\mathrm{Mg}(\mathrm{mg} / \mathrm{L})$ & 0.43 \\
\hline $\mathrm{Zn}(\mathrm{mg} / \mathrm{L})$ & 2.00 \\
\hline $\mathrm{Mn}(\mathrm{mg} / \mathrm{L})$ & 2.26 \\
\hline $\mathrm{Fe}(\mathrm{mg} / \mathrm{L})$ & 70.82 \\
\hline
\end{tabular}

*Analyzed according to CLA/PSO/13/2013 standard;

**analyzed according to KQ/PB-76; other elements analyzed according to KQ/PB-17 standard microscopic strainers from Farmet DUO (Czech Republic) in the continuous operation mode. The press was started and after the stabilization of the working temperature the oil pressing process commenced. Stabilization was achieved after the pressing of oil from a mass of about 1 $\mathrm{kg}$ of seeds when the temperature was about $70^{\circ} \mathrm{C}$. The temperature during pressing was measured with the aim of an ama-digit thermometer. The oil after extrusion was stored in dark glass bottles at a $5^{\circ} \mathrm{C}$ in order to obtain natural decantation for six days and then be subjected to analyses monthly during a three-month period of storage.

\section{Determining Chlorophylls and Carotenoids}

Chlorophyll and carotenoid content was determined spectrophotometrically using a double-beam UV-Vis Jasco V-630 spectrophotometer (Jasco International Co., Ltd., Japan). Spectra of oils diluted $20 \times$ with acetone were measured within the spectral range of 350-700 nm. Photosynthetic pigment concentrations (in $\mu \mathrm{g} / \mathrm{mL}$ ) were determined according to the procedure of Lichtenthaler and Buschmann (2001) [36], with slight modifications. Each measurement was done in three independent replications.

\section{Determining Oxidative Stability (the Rancimat Test)}

Oxidative stability was measured using a Rancimat 670 apparatus (Metrohm AG, Herisau, Switzerland). Oil samples $(2.5 \mathrm{~g})$ were weighed into reaction vessels and heated at $120^{\circ} \mathrm{C}$ under a dry air flow of $20 \mathrm{l} / \mathrm{h}$. The volatile compounds released during oxidation were collected into a cell containing distilled water, and the increasing water conductivity was continually measured. The time (expressed in hours) to reach the conductivity inflection point was recorded as the induction time (IT). The normal time was assessed based on induction time using the validation coefficient designated from the dependence between induction time and sample temperature by StabNet software controlling the Rancimat device. All determinations were carried out in triplicate.

\section{Color Parameters}

The color parameters were measured according to CIE $L^{*} a^{*} b^{*}$ color scale [37]. Prior to analysis all samples were left for $2 \mathrm{~h}$ to equilibrate at room temperature and the instrument was calibrated to a white ceramic tile (CIE $\left.L^{*}=99.25 ; a^{*}=-0.60 ; b^{*}=1.87\right)$. Standard $10 \mathrm{~mm}$ optical path length polypropylene cuvettes were filled with $4 \mathrm{ml}$ of specimens. Cuvettes were covered from three sides, except the one facing the chromameter measuring head, with cardboard providing a white background (whiteness of *****). Measurements were performed in darkness. The chroma-meter automatically generated three measurements from which it calculated a mean color measurement. Color coordinates were recorded fivefold for each sample and 
the mean $L^{*} a^{*} b^{*}$ values were calculated. The colorimetric measurements of background were taken under identical conditions.

\section{Statistical Analysis}

Results are presented as means \pm standard deviation from three (or five, as indicated) replicates of each experiment. Significant differences $(p<0.05)$ between mean values were determined by the analysis of variance, Pearson correlation, and post-hoc Tuckey tests (ANOVA) with the assistance of Statistica 10 software.

\section{Results and Discussion}

The physico-chemical characteristics of digestate vary substantially according to the operating conditions of the anaerobic digestion (AD) plant (e.g., temperature), the season, and pre-treatment technologies. Chemical composition of a liquid fraction is also highly dependent on the efficiency of the used solid/liquid separation devices [38]. The digestate agronomic characteristics (including organic matter content) and quality as well as plant-available nutrients and possibly harmful properties, e.g., heavy metals and pathogens, define the effect on soils and plants [38]. Analysis indicates that the used digestate contained less nitrogen, phosphorus, and potassium as compared to the applied NPK commercial fertilizer: $0.119,0.12$, and $5.37 \mathrm{~g} / \mathrm{L}$, respectively. The use of mixtures of plant materials in the process of producing digestate contributes to the increase in the heavy metals concentration $(\mathrm{Cr}, \mathrm{Hg}, \mathrm{Pb}, \mathrm{Zn}$, etc.) [39]. Analysis of the digestate composition showed that the content of heavy metals was within the accepted level, thus indicating the possibility of its use as fertilizer. Digestate in this study was slightly alkaline with $\mathrm{pH}$
8.73, typical for food and green waste digestates, and its $\mathrm{pH}$ was higher as compared to digestates characterized in other studies ( $\mathrm{pH}$ 6.7-8.4) [39]. The $\mathrm{pH}$, solids concentrations of the digestate, and feedstock are usually assessed to evaluate the effect of digestate on soil quality and plant growth. The use of alkaline digestate could increase $\mathrm{NH}_{4}-\mathrm{N}$ volatilization from soil during spreading, depending on the temperature [40], and the acidic digestates can decrease soil $\mathrm{pH}$ and enhance heavy metal mobilization in soils [41]. Subsequently, the effect of digestate $\mathrm{pH}$ on soil is dependent on soil characteristics [42].

It is known that the oxidation of oils depends on many factors which include the composition of unsaturated fatty acids that are the most susceptible to oxidation reactions, storage conditions (heat or light), and concentration of oxygen, as well as the presence of transition metals, peroxides, or antioxidants [43]. Fatty acid composition varies in vegetable oils from different sources, mainly depending on cultivar, but also on ripeness and on the area of cultivation and climatic conditions [44]. Rapeseed oil has a well-balanced proportion of linoleic (C18:2; $\mathrm{n}-6)$ and $\alpha$-linolenic acid (C18:3; n-3) at a 2:1 ratio [45].

In the presented study control seeds contained between 62.4 and 65.0 of oleic acid, $18.2-20.5 \%$ of linoleic acid, and $6.7-7.2 \%$ of linolenic acid (Table 2). The previous reports showed that the composition of the fatty acid of rapeseed amounted to c.a. $60 \%$ for oleic acid, c.a. $21 \%$ for linoleic acid, and c.a $10 \%$ for linoleic acid [44-48]. Statistical analysis by post-hoc Tukey test showed that the 'Bios' cultivar contained a significantly higher amount of oleic acid, 'Feliks' had the highest amount of linoleic acid, and 'Markus' contained the highest amount of linolenic acid. Concerning the use of digestate or NPK fertilizer in growing the examined cultivars, a statistically significant decrease in oleic acid content (in respect to control) was observed for 'Bios', and a statistically significant increase

Table 2. Fatty acid content of seeds.

\begin{tabular}{|c|c|c|c|c|}
\hline \multirow{2}{*}{ Experiment } & \multirow{2}{*}{ Cultivar } & \multicolumn{3}{|c|}{ Content (\%) } \\
\cline { 2 - 5 } & 'Bios' & $\mathrm{C} 18: 1$ & C18:2 & \multicolumn{2}{|c|}{ C18:3 } \\
\hline \multirow{3}{*}{ Control } & 'Markus' & $65.0 \pm 0.6 \mathrm{a}^{\mathrm{A}}$ & $18.2 \pm 0.6 \mathrm{a}^{\mathrm{A}}$ & $6.7 \pm 0.2 \mathrm{a}^{\mathrm{A}}$ \\
\cline { 2 - 5 } & 'Feliks' & $64.6 \pm 0.6 \mathrm{~b}^{\mathrm{C}}$ & $18.5 \pm 0.7 \mathrm{a}^{\mathrm{A}}$ & $7.2 \pm 0.2 \mathrm{~b}^{\mathrm{A}}$ \\
\cline { 2 - 5 } & 'Bios' & $62.4 \pm 0.3 \mathrm{c}^{\mathrm{B}}$ & $20.5 \pm 0.3 \mathrm{~b}^{\mathrm{B}}$ & $6.9 \pm 0.2 \mathrm{a}^{\mathrm{A}}$ \\
\hline \multirow{3}{*}{ Digestate } & 'Markus' & $64.8 \pm 0.5 \mathrm{a}^{\mathrm{B}}$ & $18.7 \pm 0.7 \mathrm{a}^{\mathrm{A}}$ & $7.6 \pm 0.2 \mathrm{~b}^{\mathrm{A}}$ \\
\cline { 2 - 5 } & 'Feliks' & $65.8 \pm 0.7 \mathrm{c}^{\mathrm{A}}$ & $18.0 \pm 0.8 \mathrm{a}^{\mathrm{A}}$ & $6.4 \pm 0.2 \mathrm{a}^{\mathrm{A}}$ \\
\cline { 2 - 5 } & 'Bios' & $64.2 \pm 0.5 \mathrm{a}^{\mathrm{C}}$ & $18.5 \pm 0.7 \mathrm{a}^{\mathrm{A}}$ & $6.2 \pm 0.2 \mathrm{a}^{\mathrm{A}}$ \\
\hline \multirow{3}{*}{ NPK fertilizer } & 'Markus' & $65.2 \pm 0.6 \mathrm{~b}^{\mathrm{A}}$ & $17.9 \pm 0.5 \mathrm{a}^{\mathrm{A}}$ & $6.5 \pm 0.2 \mathrm{a}^{\mathrm{A}}$ \\
\cline { 2 - 5 } & 'Feliks' & $65.5 \pm 0.7 \mathrm{~b}^{\mathrm{A}}$ & $18.0 \pm 0.5 \mathrm{a}^{\mathrm{A}}$ & $6.3 \pm 0.2 \mathrm{a}^{\mathrm{A}}$ \\
\hline
\end{tabular}

Values marked with the same letter are not statistically significantly different $(\mathrm{p}<0.05)$

a-c: differences between cultivars in the experimental group

A-C: differences between samples characterized by usage of different fertilizer and controls $(N=27)$ 


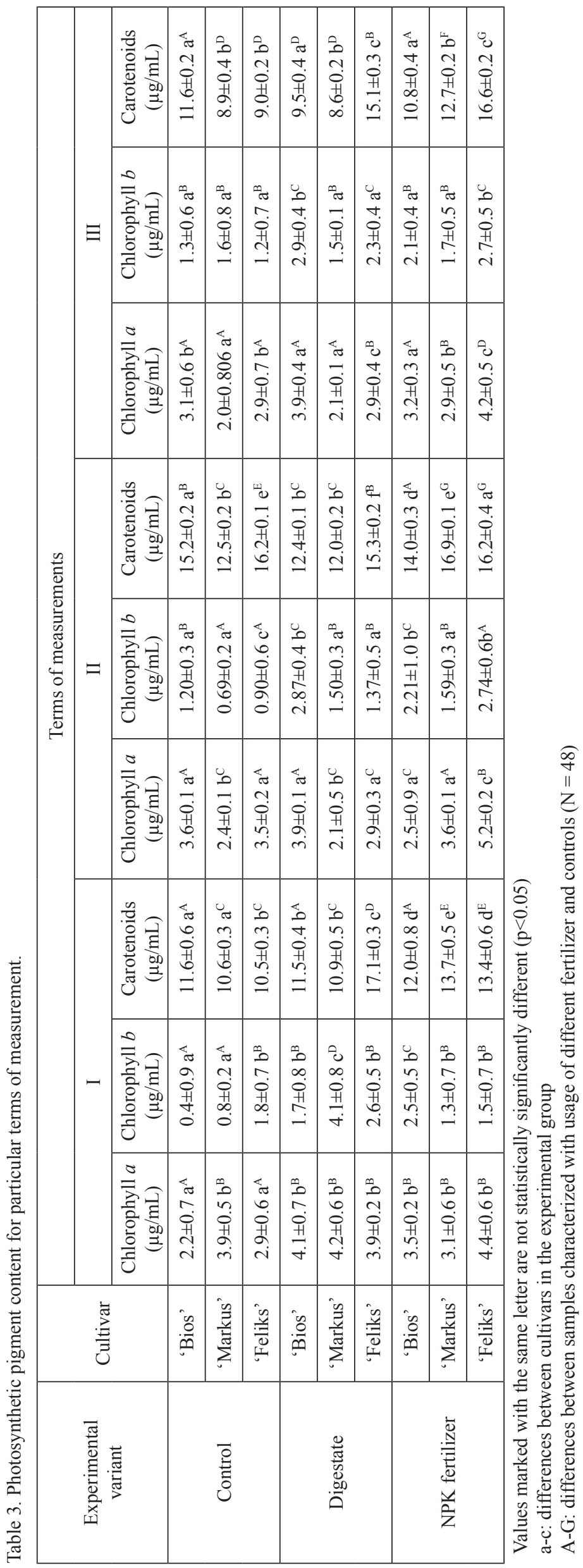


Table 4. Analysis of the induction and normal time (h) of oils.

\begin{tabular}{|c|c|c|c|c|c|c|}
\hline \multirow{2}{*}{ Parameter } & \multirow{2}{*}{ arameter } & \multirow{2}{*}{ Experimental variant } & \multirow{2}{*}{ Cultivar } & \multicolumn{3}{|c|}{ Terms of measurements } \\
\hline & & & & I & II & III \\
\hline \multirow{18}{*}{ 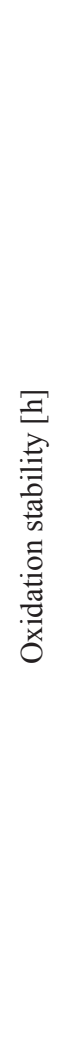 } & Induction time & \multirow{6}{*}{ Control } & \multirow{2}{*}{ 'Bios' } & $8.3 \pm 0.1 \mathrm{a}^{\mathrm{A}}$ & $4.1 \pm 0.4 \mathrm{a}^{\mathrm{A}}$ & $2.13 \pm 0.1 \mathrm{a}^{\mathrm{A}}$ \\
\hline & Normal time & & & $23.7 \pm 0.5 \mathrm{a}^{\mathrm{E}}$ & $21.4 \pm 0.1 \mathrm{c}^{\mathrm{E}}$ & $20.18 \pm 0.2 \mathrm{a}^{\mathrm{E}}$ \\
\hline & Induction time & & & $8.4 \pm 0.6 \mathrm{a}^{\mathrm{A}}$ & $7.7 \pm 0.2 \mathrm{~b}^{\mathrm{B}}$ & $4.86 \pm 0.1 \mathrm{~b}^{\mathrm{B}}$ \\
\hline & Normal time & & & $21.8 \pm 0.5 \mathrm{~b}^{\mathrm{F}}$ & $20.5 \pm 0.1 \mathrm{a}^{\mathrm{E}}$ & $19.89 \pm 0.4 b^{\mathrm{E}}$ \\
\hline & Induction time & & \multirow{2}{*}{ 'Feliks' } & $8.3 \pm 0.1 \mathrm{a}^{\mathrm{A}}$ & $7.0 \pm 0.1 \mathrm{~b}^{\mathrm{C}}$ & $3.72 \pm 0.1 \mathrm{c}^{\mathrm{C}}$ \\
\hline & Normal time & & & $21.3 \pm 0.9 \mathrm{a}^{\mathrm{F}}$ & $19.9 \pm 0.4 b^{F}$ & $18.03 \pm 0.1 \mathrm{c}^{\mathrm{F}}$ \\
\hline & Induction time & \multirow{6}{*}{ Digestate } & \multirow{2}{*}{ 'Bios' } & $7.9 \pm 0.4 \mathrm{a}^{\mathrm{A}}$ & $5.2 \pm 0.1 \mathrm{~b}^{\mathrm{B}}$ & $3.5 \pm 0.4 \mathrm{a}^{\mathrm{B}}$ \\
\hline & Normal time & & & $20.9 \pm 0.1 \mathrm{~b}^{\mathrm{F}}$ & $18.5 \pm 0.9 \mathrm{~b}^{\mathrm{F}}$ & $13.2 \pm 0.1 \mathrm{a}^{\mathrm{G}}$ \\
\hline & Induction time & & , & $7.7 \pm 0.2 \mathrm{a}^{\mathrm{A}}$ & $5.3 \pm 0.3 \mathrm{~b}^{\mathrm{C}}$ & $0.5 \pm 0.1 \mathrm{~b}^{\mathrm{D}}$ \\
\hline & Normal time & & 1Vก & $21.4 \pm 0.1 \mathrm{~b}^{\mathrm{F}}$ & $19.8 \pm 0.5 \mathrm{c}^{\mathrm{F}}$ & $17.5 \pm 0.7 \mathrm{~b}^{\mathrm{F}}$ \\
\hline & Induction time & & \multirow{2}{*}{ 'Feliks' } & $8.2 \pm 0.1 \mathrm{a}^{\mathrm{A}}$ & $4.0 \pm 0.4 \mathrm{~b}^{\mathrm{D}}$ & $0.3 \pm 0.1 \mathrm{~b}^{\mathrm{D}}$ \\
\hline & Normal time & & & $21.7 \pm 0.4 \mathrm{a}^{\mathrm{F}}$ & $21.6 \pm 0.1 \mathrm{a}^{\mathrm{E}}$ & $20.9 \pm 0.1 \mathrm{c}^{\mathrm{E}}$ \\
\hline & Induction time & \multirow{6}{*}{ NPK fertilizer } & \multirow{2}{*}{ 'Bios' } & $8.4 \pm 0.1 \mathrm{a}^{\mathrm{A}}$ & $7.9 \pm 0.1 \mathrm{a}^{\mathrm{B}}$ & $3.7 \pm 0.1 \mathrm{~b}^{\mathrm{B}}$ \\
\hline & Normal time & & & $22.0 \pm 0.2 \mathrm{~b}^{\mathrm{F}}$ & $20.4 \pm 0.3 \mathrm{a}^{\mathrm{E}}$ & $19.7 \pm 0.6 \mathrm{a}^{\mathrm{E}}$ \\
\hline & Induction time & & & $9.3 \pm 0.1 \mathrm{a}^{\mathrm{A}}$ & $8.9 \pm 0.1 \mathrm{~b}^{\mathrm{C}}$ & $7.1 \pm 0.1 \mathrm{a}^{\mathrm{D}}$ \\
\hline & Normal time & & & $23.9 \pm 0.7 \mathrm{c}^{\mathrm{E}}$ & $23.7 \pm 0.3 \mathrm{~b}^{\mathrm{G}}$ & $18.2 \pm 0.1 \mathrm{~b}^{\mathrm{G}}$ \\
\hline & Induction time & & & $8.5 \pm 0.2 \mathrm{a}^{\mathrm{A}}$ & $8.0 \pm 0.4 \mathrm{a}^{\mathrm{B}}$ & $3.8 \pm 0.2 \mathrm{~b}^{\mathrm{C}}$ \\
\hline & Normal time & & & $21.8 \pm 0.8 \mathrm{a}^{\mathrm{F}}$ & $20.6 \pm 0.1 \mathrm{a}^{\mathrm{E}}$ & $20.5 \pm 0.9 c^{\mathrm{E}}$ \\
\hline
\end{tabular}

$\mathrm{a}, \mathrm{b}, \mathrm{c}, \mathrm{d}$, e: average values marked with the same letter are not statistically significantly different $(\mathrm{p}<0.05)$; $\mathrm{C}$ : control

in 'Feliks'. Concerning the linolenic acid content, a statistically significant decrease (in respect to control) was observed for 'Feliks'. No statistical changes in the content of linolenic acid were observed.

Carotenoids and chlorophylls are characterized by considerable antioxidant activity, especially at the "quenching" of singlet oxygen generated by photosensitizers like chlorophylls [50]. Crude canola oil frequently contains chlorophyll and chlorophyll derivatives, such as pheophytins $a$ and $b$ and pyropheophytins $a$ and $b$. The levels of these undesirable pigments are higher in oil extracted from unripened seeds $[49,51]$. Table 3 summarizes the results of analysing the contents of chlorophylls and carotenoids in the pressed oils. Concentrations of chlorophyll $a$ estimated in the first term ranged 2.2-4.4 $\mu \mathrm{g} / \mathrm{mL}$, chl. $b \quad 0.4-4.1 \mu \mathrm{g} / \mathrm{mL}$, and carotenoids 10.4-17.1 $\mu \mathrm{g} / \mathrm{mL}$. Concentrations of photosynthetic pigments measured in the second term were similar or slightly higher than those registered for the first term. The contents of chlorophyll $a$ ranged 2.1-5.2 $\mu \mathrm{g} / \mathrm{mL}$, chlorophyll $b \quad 0.7-2.9 \mu \mathrm{g} / \mathrm{mL}$, and carotenoids $12.0-19.4 \mu \mathrm{g} / \mathrm{mL}$. In the third term the trend in most cases was the decrease in content of both chlorophylls $a$ and $b$, and carotenoids. Analysis of chlorophyll and carotenoid content in the examined oils during the first measuring period showed high contents of these compounds as compared to oil from rapeseed bred with the application of commercial NPK fertilizer published previously (chl. $a-1.8 \mu \mathrm{g} / \mathrm{ml}$, chl. $b-2.0 \mu \mathrm{g} / \mathrm{ml}$, carotenoids $-8.4 \mu \mathrm{g} / \mathrm{ml}$ ) [52]. The results of the statistical analysis with use of post-hoc Tuckey tests confirmed statistically significant differences between the terms of measurements and the content of photosynthetic pigments in most cases.

In the first term, concerning concentrations of all photosynthetic pigments, the statistical effect from fertilizer was observed for 'Bios' and 'Feliks' as compared to control. The observed effect of the cultivar was significant between cultivars in control. In the second term the statistical effect on concentrations of chlorophyll $a$ was registered for samples characterized by the use of NPK fertilizer while statistical effects on chlorophyll $b$ were found for NPK fertilizer - both respective to control. In the third term the effect of cultivar on chlorophyll content was observed for NPK fertilizer as compared to control. In the case of carotenoids, the effect of cultivar was observed for NPK fertilizer as compared to control and digestate. The effect of fertilizer was observed in the case of chlorophyll $a$ for 'Feliks'. In the case of chlorophyll $b$, statistical differences were observed for 'Bios' between control and digestate and between control and between digestate and NPK fertilizer. Concerning 
Table 5. Analysis of the colors of the samples of rapeseed oil according to the CIE L*a*b*standards.

\begin{tabular}{|c|c|c|c|c|c|c|c|c|}
\hline \multirow{2}{*}{ Fertilizer } & \multicolumn{8}{|c|}{ Specification } \\
\hline & Cultivar & Term & $\mathrm{L}^{*}$ & $a^{*}$ & $\mathrm{~b}^{*}$ & $\mathrm{~h}$ & Chroma & $\Delta \mathrm{H}$ \\
\hline \multirow{9}{*}{ Control } & 'Bios' & \multirow{3}{*}{ I } & $10.4 \pm 0.5 \mathrm{a}$ & $0.2 \pm 0.1 \mathrm{a}$ & $15.7 \pm 0.7 \mathrm{a}$ & 1. $6 \pm 0.1 \mathrm{a}$ & $15.7 \pm 0.7 \mathrm{a}$ & $17.5 \pm 0.8 \mathrm{a}$ \\
\hline & 'Markus' & & $9.7 \pm 0.4 \mathrm{a}$ & $0.3 \pm 0.1 \mathrm{a}$ & $14.3 \pm 0.6 \mathrm{a}$ & $1.5 \pm 0.1 \mathrm{a}$ & $14.3 \pm 0.6 \mathrm{~g}$ & $15.9 \pm 0.7 \mathrm{~b}$ \\
\hline & 'Feliks' & & $7.6 \pm 1.0 \mathrm{~b}$ & $1.5 \pm 0.1 \mathrm{a}$ & $11.0 \pm 1.7 \mathrm{~b}$ & $1.4 \pm 0.1 \mathrm{a}$ & $11.1 \pm 1.7 \mathrm{~b}$ & $12.0 \pm 2.0 \mathrm{c}$ \\
\hline & 'Bios’' & \multirow{3}{*}{ II } & $13.6 \pm 0.5 \mathrm{~d}$ & $-0.4 \pm 0.1 \mathrm{a}$ & $21.5 \pm 0.8 \mathrm{~d}$ & $-1.5 \pm 0.1 \mathrm{~d}$ & $21.5 \pm 0.8 \mathrm{~d}$ & $24.3 \pm 1.0 \mathrm{~d}$ \\
\hline & 'Markus' & & $13.5 \pm 0.5 \mathrm{~d}$ & $-0.5 \pm 0.1 \mathrm{c}$ & $21.1 \pm 0.9 \mathrm{~d}$ & $-1.5 \pm 0.1 b$ & $21.1 \pm 0.9 \mathrm{~d}$ & 23. $8 \pm 1.0 \mathrm{~d}$ \\
\hline & 'Feliks' & & $11.3 \pm 0.2 \mathrm{a}$ & $0.9 \pm 0.1 \mathrm{a}$ & $17.7 \pm 0.4 \mathrm{~g}$ & $1.52 \pm 0.1 \mathrm{~b}$ & $17.7 \pm 0.4 \mathrm{~b}$ & $19.7 \pm 0.5 \mathrm{f}$ \\
\hline & 'Bios' & \multirow{3}{*}{ III } & $13.7 \pm 0.7 \mathrm{~d}$ & $-0.4 \pm 0.1 \mathrm{c}$ & $20.7 \pm 1.1 \mathrm{~d}$ & $-1.5 \pm 0.1 \mathrm{a}$ & $20.7 \pm 1.1 \mathrm{~d}$ & $23.5 \pm 1.3 \mathrm{~d}$ \\
\hline & 'Markus' & & $11.8 \pm 0.6 \mathrm{a}$ & $-0.4 \pm 0.4 \mathrm{c}$ & $18.6 \pm 1.1 \mathrm{e}$ & $-1.5 \pm 0.1 \mathrm{~b}$ & $18.6 \pm 1.1 \mathrm{e}$ & $20.9 \pm 1.3 \mathrm{~g}$ \\
\hline & 'Feliks' & & $10.7 \pm 0.7 \mathrm{a}$ & $0.8 \pm 0.2 \mathrm{a}$ & $16.9 \pm 1.3 \mathrm{~g}$ & $1.5 \pm 0.1 \mathrm{a}$ & $17.0 \pm 1.3 \mathrm{a}$ & $18.9 \pm 1.5 \mathrm{a}$ \\
\hline \multirow{9}{*}{ Digestate } & 'Bios' & \multirow{3}{*}{ I } & $10.2 \pm 0.4 \mathrm{a}$ & $0.4 \pm 0.1 \mathrm{a}$ & $15.1 \pm 0.5 \mathrm{a}$ & $1.5 \pm 0.1 \mathrm{a}$ & $15.1 \pm 0.5 \mathrm{a}$ & $18.0 \pm 1.2 \mathrm{a}$ \\
\hline & 'Markus' & & $10.4 \pm 0.3 \mathrm{a}$ & $0.2 \pm 0.1 \mathrm{a}$ & $15.5 \pm 0.6 \mathrm{a}$ & $1.5 \pm 0.1 \mathrm{a}$ & $15.5 \pm 0.6 \mathrm{a}$ & $17.3 \pm 0.6 \mathrm{a}$ \\
\hline & 'Feliks' & & $9.3 \pm 0.6 \mathrm{c}$ & $0.8 \pm 0.1 \mathrm{~b}$ & $13.6 \pm 1.0 \mathrm{c}$ & $1.5 \pm 0.1 \mathrm{a}$ & $13.6 \pm 1.0 \mathrm{c}$ & $15.0 \pm 1.2 \mathrm{~b}$ \\
\hline & 'Bios' & \multirow{3}{*}{ II } & $11.9 \pm 0.7 \mathrm{c}$ & $-0.2 \pm 0.1 \mathrm{c}$ & $18.6 \pm 1.2 \mathrm{e}$ & $-1.6 \pm 0.1 b$ & $18.6 \pm 1.2 \mathrm{e}$ & $21.5 \pm 1.0 \mathrm{e}$ \\
\hline & 'Markus' & & $12.6 \pm 0.3 \mathrm{~d}$ & $-0.2 \pm 0.1 \mathrm{c}$ & $19.6 \pm 0.5 \mathrm{f}$ & $-1.5 \pm 0.1 b$ & $19.6 \pm 0.5 \mathrm{e}$ & $22.1 \pm 0.6 \mathrm{e}$ \\
\hline & 'Feliks' & & $11.8 \pm 0.3 \mathrm{a}$ & $0.4 \pm 0.1 \mathrm{a}$ & $18.5 \pm 0.4 \mathrm{f}$ & $1.5 \pm 0.1 \mathrm{a}$ & $18.5 \pm 0.4 \mathrm{e}$ & $20.7 \pm 0.5 \mathrm{~g}$ \\
\hline & 'Bios' & \multirow{3}{*}{ III } & $13.1 \pm 0.5 \mathrm{~d}$ & $0.1 \pm 0.1 \mathrm{a}$ & $20.9 \pm 0.8 \mathrm{~d}$ & $1.6 \pm 0.1 \mathrm{a}$ & $20.9 \pm 0.8 \mathrm{~d}$ & 23. $6 \pm 0.8 \mathrm{~d}$ \\
\hline & 'Markus' & & $11.67 \pm 0.5 \mathrm{a}$ & $-0.3 \pm 0.2 \mathrm{c}$ & 17. $8 \pm 0.9 \mathrm{~g}$ & $-1.5 \pm 0.1 b$ & $17.8 \pm 0.9 \mathrm{~b}$ & $20.0 \pm 1.0 \mathrm{~g}$ \\
\hline & 'Feliks' & & $10.3 \pm 0.6 \mathrm{a}$ & $0.5 \pm 0.3 \mathrm{a}$ & $16.7 \pm 1.3 \mathrm{~g}$ & $1.5 \pm 0.1 \mathrm{a}$ & $16.7 \pm 1.3 \mathrm{a}$ & 18. $7 \pm 1.4 \mathrm{a}$ \\
\hline \multirow{9}{*}{$\begin{array}{c}\text { NPK } \\
\text { fertilizer }\end{array}$} & Bios' & \multirow{3}{*}{ I } & $10.1 \pm 1.0 \mathrm{a}$ & $-0.1 \pm 0.1 \mathrm{c}$ & $14.0 \pm 0.9 \mathrm{a}$ & $-1.6 \pm 0.1 b$ & $14.0 \pm 0.9 \mathrm{~g}$ & $17.5 \pm 0.6 \mathrm{a}$ \\
\hline & 'Markus' & & $9.7 \pm 0.8 \mathrm{a}$ & $0.4 \pm 0.1 \mathrm{a}$ & $14.4 \pm 1.2 \mathrm{a}$ & $1.5 \pm 0.1 \mathrm{a}$ & $14.4 \pm 1.2 \mathrm{~g}$ & $16.0 \pm 1.4 \mathrm{~b}$ \\
\hline & 'Feliks' & & $10.3 \pm 0.3 \mathrm{a}$ & $0.5 \pm 0.1 \mathrm{a}$ & $14.6 \pm 0.5 \mathrm{a}$ & $1.5 \pm 0.1 \mathrm{a}$ & $14.7 \pm 0.5 \mathrm{~g}$ & $16,4 \pm 0.5 b$ \\
\hline & 'Bios' & \multirow{3}{*}{ II } & $13.2 \pm 0.2 \mathrm{~d}$ & $-0.3 \pm 0.1 \mathrm{c}$ & $20.7 \pm 0.3 \mathrm{~d}$ & $-1.6 \pm 0.1 b$ & $20.7 \pm 0.3 \mathrm{~d}$ & $23,5 \pm 0.3 \mathrm{~d}$ \\
\hline & 'Markus' & & $12.5 \pm 0.5 \mathrm{e}$ & $-0.1 \pm 0.1 \mathrm{c}$ & $19.6 \pm 0.8 \mathrm{f}$ & $-1.6 \pm 0.1 b$ & $19.6 \pm 0.8 \mathrm{e}$ & $22.1 \pm 0.9 \mathrm{e}$ \\
\hline & 'Feliks' & & $13.0 \pm 0.5 \mathrm{~d}$ & $0.3 \pm 0.1 \mathrm{a}$ & $20.4 \pm 0.6 \mathrm{~d}$ & $-1.5 \pm 0.1 b$ & $22.6 \pm 0.4 \mathrm{f}$ & $25.6 \pm 0.4 \mathrm{~d}$ \\
\hline & 'Bios' & \multirow{3}{*}{ III } & $12.5 \pm 0.5 \mathrm{e}$ & $-0.5 \pm 0.2 \mathrm{c}$ & $20.1 \pm 0.8 \mathrm{~d}$ & $-1.5 \pm 0.1 \mathrm{~b}$ & $20.1 \pm 0.8 \mathrm{~d}$ & $23.0 \pm 0.6 \mathrm{e}$ \\
\hline & 'Markus' & & $12.0 \pm 0.8 \mathrm{a}$ & $-0.4 \pm 0.2 \mathrm{c}$ & $18.3 \pm 1.4 \mathrm{e}$ & $-1.5 \pm 0.1 \mathrm{~b}$ & $18.3 \pm 1.4 \mathrm{e}$ & $20.6 \pm 1.6 \mathrm{~g}$ \\
\hline & 'Feliks' & & $12.3 \pm 0.1 \mathrm{e}$ & $-0.2 \pm 0.1 \mathrm{c}$ & $18.6 \pm 1.7 \mathrm{e}$ & $-1.6 \pm 0.1 \mathrm{~b}$ & $18.6 \pm 1.7 \mathrm{e}$ & $21.0 \pm 1.9 \mathrm{~g}$ \\
\hline
\end{tabular}

a-h: average values marked with the same letter are not statistically significantly different $(\mathrm{p}<0.05)(\mathrm{N}=166)$

carotenoid content the effect of fertilizer was observed for all cultivars as compared to control.

Oxidative stability of the oils is affected by many factors such as fatty acids composition, the presence of antioxidants, and small compounds [53]. Table 4 shows the results of analysis of the oxidative stability of the examined oils. The results clearly show that the oxidative stability (induction time) of the oils and the normal time are decreasing in the subsequent measuring terms in the case of each experimental variant. Oils produced with the use of traditional NPK fertilizer were generally characterized by higher oxidation stability as compared to controls and to that produced with the use of digestate.
Induction times found for controls of all cultivars were similar and no statistical differences were found. Normal time observed for 'Markus' (8.4 h) was statistically different from the others (lower than 'Bios' and 'Markus' at $8.3 \mathrm{~h}$ ). The highest induction time in the first term was found for 'Feliks' (8.5 h) grown on NPK fertilizer, while the lowest was for 'Markus' bred on digestate $(7.7 \mathrm{~h})$. The highest induction time in the second term was found for 'Markus' (8.9 h) produced with the use of NPK fertilizer, and the lowest for 'Feliks' bred with use of digestate.

The highest induction time in the third term was found for 'Markus' grown on NPK fertilizer, and the lowest for 'Markus' grown on digestate $(7.7 \mathrm{~h})$. The use of digestate 
generally produced an effect of decreased induction time. Statistical effects were found for the second and third terms for 'Markus' and 'Feliks'. Although an increase in induction time was observed in all the measurement terms for oils extracted from seeds produced with the use of NPK fertilizer for all the terms of measurements, statistical differences were found for the second (all cultivars) and third terms of measurement ('Bios' and 'Markus'). No statistical differences concerning induction time were found for the first term of measurements except for the statistical difference in control group between 'Bios' and other cultivars. The statistical effect of cultivar was found for controls in the second term between 'Bios' and other cultivars as well as for the group produced with the NPK fertilizer between 'Markus' and other cultivars.

Oxidative stability parameters obtained in this study in most cases were relatively high in both analyzed variants, especially in the first period of measurement, and were higher than obtained previously for a winter rape oil (4.0h) [52].

In our case the seeds were not subjected to any process of heating prior to oil pressing in order to achieve greater efficiency of the resulting oil. The previously reported oxidation stability was lower than that obtained in this study [50]. A similar induction time was obtained after heating the seeds for $2(5 \mathrm{~h})$ or 4 min ( 8 hours) in a microwave [53-54]. Such high oxidative stability in the first month of storage can be explained by the relatively high content of compounds that function as antioxidants, i.e., the presence of carotenoids and chlorophylls in our case.

Table 5 shows the parameters characterizing colors of the examined oils. As can be seen, the color of the different cultivars during different terms of measurements varies considerably. All the oils are relatively dark, as shown by the luminosity $L^{*}$ from the range of 7.6 to 13.7. For the control samples and oils obtained from seeds cultivated on digestate initially the color is yellow ( $\mathrm{b}^{*}$ between 11.0 and 21.5) with an admix of green (positive values of $a^{*}$ ). With time, the color becomes more intense and the admixture passes into red (negative $\mathrm{a}^{*}$ values).

Parameter $\mathrm{L}^{*}$ increases with time, which indicates change in the initial yellow color. Hue angle $h$ refers to pure color in terms of shade. As seen, the oils are generally yellow with a tint of other colors. In the case of positive $\mathrm{h}$ values this indicates the addition of green, and in the case of negative values the addition of red. As seen from hue angle $\mathrm{h}$ the admix of green is observed exclusively for control samples in the first term of measurements. Chroma of the color is the measure of how pure or intense the color is. Since it can take values between 0 and 100 it is indication of other components. $\Delta \mathrm{H}=1$ is the smallest color difference the human eye can see. Therefore it can be noticed that although there is a slight difference in colour between the oils originating from plants grown on digestate or commercial fertilizer, there is an increase in that parameter over time, which clearly indicates darkening of the oils in most cases.
Statistical analysis at a significance level $\mathrm{p}<0.05$ showed statistically significant correlation $(-0.097)$ between the oil cultivars and $\mathrm{L}^{*}$ parameter, as well as between the oil cultivars and the distance from the background $\Delta \mathrm{H}(-0.13)$. Statistically significant correlations were found between all the colour parameters and terms of measurements (L:0.61, a*: $-0.38, \mathrm{~b}^{*}: 0.64$, h:-0.33, chroma: 0.64 and $\left.\Delta \mathrm{H}: 0.62\right)$ as well as between the applied fertilizer and colour parameters (L:0.16, a*: $-0.37, \mathrm{~b}^{*}: 0.12$, h:-0.29, chroma: 0.11 and $\Delta \mathrm{H}: 0.14)$. Strong correlation was found between induction time and the terms of measurements: $0.95,0.94$, and 0.97 for first, second, and third terms, respectively.

\section{Conclusions}

1. Seeds from the 'Bios' cultivar bred with the use of digestate showed a lower amount of oleic acid (C18:1),while seeds from 'Feliks' had higher content of this fatty acid and lower amounts of linoleic acid (C18:2) as compared to respective controls.

2. In the case of the application of NPK fertilizer, the increase in C18:1 was observed for seeds from 'Markus' and 'Feliks'. In the latter the decrease in the content of C18:2 was observed as compared to control.

3. The increase in chlorophyll content upon using both fertilizers were found during the first measurement term as compared to control.

4. Oils derived from seeds produced with the use of commercial NPK fertilizer were characterized by a higher oxidation stability (induction time) as compared to digestate.

5. Gradual darkening of the oils was observed. All the oils were relatively intense in yellow color with a tint of green at initial storing stage passing into a red admixture. This effect was most visible for control and the sample produced using digestate.

\section{References}

1. CETIN M., SEVIK H. Measuring the Impact of Selected Plants on Indoor $\mathrm{CO}_{2}$ Concentrations. Polish Journal of Environmental Studies, 25 (3), 973, 2016.

2. STOKNES K., SCHOLWIN F., KRZESIŃSKI W., WOJCIECHOWSKA E., JASIŃKA A. Efficiency of a novel "Food to waste to food" system including anaerobic digestion of food waste and cultivation of vegetables on digestate in a bubble-insulated greenhouse. Waste Management, 56, 466, 2016.

3. ALBURQUERQUE J.A., DE LA FUENTE C., BERNAL M.P., Chemical properties of anaerobic digestates affecting $\mathrm{C}$ and $\mathrm{N}$ dynamics in amended soils. Agr. Ecosyst. Environ. 160, 15, 2012.

4. VANEECKHAUTE C., GHEKIERE G., MICHELS E., VANROLLEGHEM P.A., TACK F.M.G., MEERS E. The use of digestates and recovered ammonium sulfate from $\mathrm{NH}_{3}$-scrubbing as sustainable substitutes for chemical fertilizers: A field-scale assessment. IN: Global Challenges: 
Sustainable Wastewater Treatment and Resource Recovery, IWA Specialist conference, Papers, 1, 2014.

5. SZYD OWSKA-CZERNIAK A., TROKOWSKI K., KARLVITS G., SZLYK E. Determination of antioxidant capacity, phenolic acids, and fatty acid composition of rapeseed varieties. J. Agricul. Food Chem. 58, 7502, 2010.

6. Codex Stan. Codex standard for named vegetable oil. FAO/ WHO, Rome (CODEX STAN 210-1999) 2013.

7. DEMMIG-ADAMS B., ADAMS W. Antioxidants in Photosynthesis and Human Nutrition. Science 13 (298), 2149, 2002.

8. GAMMONE M.A. RICCIONI G., D’ORAZIO N. Carotenoids: Potential allies for cardiovascular health? Food Nutr. Res. 59, 26762, 2015.

9. CETIN M. Changes in the Amount of Chlorophyll in Some Plants of Landscape Studies, Kastamonu Univ., Journal of Forestry Faculty, 16 (1), 239, 2016.

10. AUGUSTA A., ODORISSI X, PÉREZ-GÁlVEZ A., Carotenoids as a Source of Antioxidants in the Diet. In: Carotenoids in Nature, Stange C. (Ed.) 2016, Volume 79 of the series Subcellular Biochemistry 359, 2016.

11. BRITTON G., LIAAEN-JENSEN S., PFANDER H. Carotenoids Handbook, Vol. 5 Birkhauser Verlag AG, Basel. 2009.

12. KREPS F, VRBIKOVÁ L., SCHMIDT Š. Influence of industrial physical refining on tocopherol, chlorophyll and beta-carotene content in sunflower and Rapeseed oil. Eur. J. Lipid Sci. Technol., 116, 1572, 2014.

13. ROTKIEWICZD., KONOPKA I., TAŃSKA M. Carotenoids and chlorophylls in plant oils and their functions. Oil Crops. XXIII, 561, 2002 [In Polish].

14. GANDUL-ROJAS B., ROCA-L. CEPERO M., MÍNGUEZMOSQUERA M.I. Use of Chlorophyll and Carotenoid Pigment Composition to Determine Authenticity of Virgin Olive Oil. J. Am. Oil Chem. Soc., 77 (8), 853, 2000.

15. SALMERÓN J.F., GÓMEZ-ROBLEDO L., CARVAJAL M.Á., HUERTAS R., MOYANO M.J., GORDILLO B., PALMA A.J., HEREDIA F.J., MELGOSA M. Measuring the colour of virgin olive oils in a new colour scale using a low-cost portable electronic device. Journal of Food Engineering. 111, 247, 2012.

16. GUNSTONE F. (Ed.). Rapeseed and Canola Oil: Production, Processing, Properties and Uses, Wiley-Blackwell Co., USA, 2009.

17. DAUN J.K. Chlorophyll in Canadian Canda and Rapeseed and its role in grading. $7^{\text {th }}$ International Rapeseed Congress, Poland, 1451, 1987.

18. ARAI H. Oxidative Modification of Lipoproteins. In: Lipid Hydroperoxide-Derived Modification of Biomolecules, Vol. 77, Subcellular Biochemistry series, 103, 2013.

19. TSUCHIHASHI H., KIGOSHI M., IWATSUKI M., NIKI E. Action of $\beta$-carotene as an antioxidant against lipid peroxidation. Arch. Biochem. Biophys. 323, 137, 1995.

20. ANUNCIATO T.P., DA ROCHA FILHO, P.A. Carotenoids and polyphenols in nutricosmetics, nutraceuticals and cosmeceuticals. J. Cosmet. Dermatol., 11, 51, 2011.

21. JOMOVA K., VALKO M. Health protective effects of carotenoids and their interactions with other biological antioxydants. Eur. J. Med. Chem. 70, 102, 2013.

22. SEVIK H.,CETIN M., BELKAYALI N. Effects of Forests on Amounts of $\mathrm{CO}_{2}$ : Case Study of Kastamonu and Ilgaz Mountain National Parks. Polish Journal of Environmental Studies, 24 (1), 253, 2015.
23. SEVIK H.,CETIN M., BELKAYALI N., GÜNEY K. Chapter 8: The Effect of Plants on Indoor Air Quality, Environmental Sustainability and Landscape Management, ST. Kliment Ohridski University Press, Eds: Recep Efe, İsa Cürebal, Abdalla Gad, Brigitta Tóth, 760, ISBN:978-95407-4140-6, chapter page: 138, 2016.

24. TAŃSKA M., ROTKIEWICZ D. The degree of conversion of selected lipids of vegetable oils and oil seeds consumer. Edible Fats. 38, 42, 2003 [In Polish].

25. FRANKEL E.N. Lipid Oxidation, $2^{\text {nd }}$ Edition, Woodhead Publishing, Philadelphia, USA, 2012.

26. GUNSTONE F.D., HARWOOD J.L., DIJKSTRA A.J. The Lipid Handbook, $3^{\text {rd }}$ Edition, CRC Press, Taylor \& Francis Group, Boca Raton, FL, USA, 2007.

27. DE LEONARDIS, A. and MACCIOLA, V. Heat-oxidation stability of palm oil blended with extra virgin olive oil. Food Chemistry,135, 1769, 2012.

28. KERRIHARD A.L., NAGY K., CRAFT B.D., PEGG R.B. Correlations among differing quantitative definitions of lipid oxidative stability in commodity fats and oils. European Journal of Lipid Science and Technology. 118 (5), 724, 2016.

29. DUBOIS V., BRETON S., LINDER M., FANNI J., PARMENTIER M. Fatty acid profiles of 80 vegetable oils with regard to their nutritional potential. European Journal of Lipid Science and Technology, 109, 710, 2007.

30. MATTHÄUS B., BRÜHL L. Why is it so difficult to produce high-quality virgin rapeseed oil for human consumption? European Journal of Lipid Science and Technology, 110, 611, 2008.

31. NAGY K., KERRIHARD A.L., BEGGIO M., CRAFT B.D., PEGG R.B. Modeling the impact of residual fatsoluble vitamin (FSV) contents on the oxidative stability of commercially refined vegetable oils. Food Research International. 84, 26, 2016.

32. GAWRYSIAK-WITULSKA M., SIGER A., NOGALAKALUCKA M. Degradation of tocopherols during nearambient rapeseed drying. J Food Lipid 16, 524, 2009.

33. MONTEDORO G., SERVILI M., BALDIOLI M., SELVAGGINI R., E., MACCHIONI A. Simple and hydrolyzable compounds in virgin olive oil. 3. Spectroscopic characterizations of the secoiridoid derivatives. J. Agric. Food Chem. 41 (11), 2228, 1993.

34. NOGALA-KALUCKA M., KORCZAK J., ELMADFA I., WAGNER K.H. Effect of a- and d-tocopherol on the oxidative stability of a mixed hydrogenated fat under frying conditions. Eur. Food Res Technol. 221, 291, 2005.

35. DECKER E.A., ELIAS R.J., MC CLEMENTS D.J. Oxidation in foods and beverages and antioxidant applications. Volume 2: Management in different industry sectors. Woodhead Publishing Limited. ISBN 978-1-84569983, 2010.

36. LICHTENTHALER H.K., BUSCHMANN C. Chlorophylls and Carotenoids: Measurement and Characterization by UVVis Spectroscopy. In: Current Protocols in Food Analytical Chemistry, Wiley \& Sons, Inc., USA., Supplement 1, F4.31-F4.3.8. 2001.

37. BRAINARD D.H. Color appearance and color difference specification. In: Science of Color (Ed. S. Shevell). Optical Society of America, Washington, DC, USA. 2003.

38. MALAMIS S., MALAMIS E., KATSOU S., DI FABIO D., BOLZONELLA F. Fatone Biological nutrients removal from the supernatant originating from the anaerobic digestion of the organic fraction of municipal solid waste. Crit. Rev. Biotechnol., 34 (3), 244, 2014. 
39. ABUBAKER J., RISBERG K., PELL M. Biogas residues as fertilisers - effect on wheat growth and soil microbial activities. Appl. Energ. 99, 126, 2012.

40. TAMPIO E., SALO T., RINTALA J. Agronomic characteristics of five different urban waste digestates. Journal of Environmental Management 169, 293, 2016.

41. TEGLIA C., TREMIER A., MARTEL J.-L.Characterization of solid digestates: part 1, review of existing indicators to assess solid digestates agricultural use. Waste Biomass Valor 2, 43, 2011.

42. NKOA R. Agricultural benefits and environmental risks of soil fertilization with anaerobic digestates: a review. Agron. Sustain. Dev. 34, 473, 2014.

43. OTABBONG E., SADOVNIKOVA L., IAKIMENKO O., NILSSON I., PERSSON J. Sewage sludge: soil conditioner and nutrient source II. Availability of $\mathrm{Cu}, \mathrm{Zn}$ and $\mathrm{Cd}$ to barley in a pot experiment. Acta Agr. Scand. B S P. 47, 65, 1997.

44. ALVARENGA P., MOURINHA C., FARTO M., SANTOS T., PALMA P., SENGO J., MORAIS M.-C., CUNHAQUEDA C. Sewage sludge, compost and other representative organic wastes as agricultural soil amendments: benefits versuslimiting factors. Waste Manage 40, 44, 2015.

45. BOSKOU, D., SIKORSKI, Z.E., KOŁAKOWSKA, A. (Eds.), Chemical and Functional Properties of Food Lipids, Taylor \& Francis, Boca Raton, FL, 325, 2003.

46. KRYGIER K., WRONIAK M., GRZEŚKIEWICZ S., OBIEDZIŃSKI M. Study on effect of destroyed seeds content on the quality of cold pressed rapeseed oil. Oil Crops. XXI, 587, 2000.
47. WRONIAK M., RĘKAS A., SIGER A., JANOWICZ M Microwave pretreatment effects on the changes in seeds microstructure, chemical composition and oxidative stability of rapeseed oil. LWT - Food Science and Technology. 68, 634, 2016.

48. DUBOIS V., BRETON S., LINDER M., FANNI J., PARMENTIER M. Fatty acid profiles of 80 vegetable oils with regard to their nutritional potential. Eur. J. Lipid Sci. Technol. 109, 710, 2007.

49. SIMOPOULOS A.P., LEAF A., SALEM JR. N. Workshop statement on the essentiality of and recommended dietary intakes for omega- 6 and omega-3 fatty acids. Prostag. Leukotr. Ess. Fatty Acids, 63, 119, 2000.

50. SCHMIDT Š. Antioxidants and oxidation changes of fats in foods, STU Bratislava, Slovakia 2010.

51. GUNSTONE F.D., NORRIS F.A. Lipids in Foods, $1^{\text {st }}$ Edn., Pergamon Press, New York, USA 1983.

52. KACHEL-JAKUBOWSKA M., SUJAK A. Evaluation of physical properties of selected vegetable oils obtained by cold pressing. Acta Agroph., 3 (4), 583, 2016.

53. AZADMARD-DAMIRCHI S., HABIBI-NODEH F., HESARI J., NEMATI M., FATHI ACHACHLOUEI B. Effect of pretreatment with microwaves on oxidative stability and nutraceuticals content of oil from rapeseed. Food Chemistry 121, 1211, 2010.

54. KOUBAA M., MHEMDI H., BARBA F.J., ROOHINEJAD S., GREINER R., VOROBIEV E. Oilseed treatment by ultrasounds and microwaves to improve oil yield and quality: An overview. Food Research International 85, 59, 2016. 